\title{
Effect of Integrated Nutrient Management on Soil Microorganisms under Irrigated Banana
}

\author{
R. Kuttimani*, E. Somasundaram and K. Velayudham \\ Agricultural Research Station, Bhavanisagr, Tamil Nadu Agricultural University, \\ Coimbatore, Tamil Nadu, India \\ *Corresponding author
}

\section{A B S T R A C T}

The present study was undertaken to find out the influence of different sources of organic manures (WG organic soil, organic grains, liquid organic manure and FYM) at different levels along with inorganic fertilizers on soil microbes and yield of banana $c v$. Grand Naine. Experiments were carried out at Agricultural Research Station, Tamil Nadu

\section{Keywords}

Bacteria, Fungi, Actinomycetes, Wellgro organic manures and farm yard manure and fertilizers.

\section{Article Info}

Accepted: 17 September 2017 Available Online: 10 November 2017 Agricultural University, Bhavanisagar during 2010-11 and 2011-12. The banana cv. Grand Naine (AAA) was used as a test crop. The experiments consisted of thirteen treatments viz., Control (100\% Recommended dose of fertilizer), four treatments consisted of WG organic soil @ 20 and 40 per cent in combination with 100 and 75 per cent RDF, two treatments consisted of 2 per cent liquid organic manure spray on bunches along with 100 and 75 per cent RDF, four treatments consisted of WG organic grains @ 20 and 40 per cent combined with 100 and 75 per cent RDF and the last two treatments comprised of FYM @ 10 kg plant ${ }^{-1}$ with 100 and 75 per cent RDF combinations. Experiments were laid out in Randomized Complete Block Design (RCBD) and treatments were replicated thrice. Study reveals that bacterial load in soil was significantly influenced through INM treatments during both the years of experiment. Among the treatments, application of 75 per cent RDF + FYM @ 10kg plant ${ }^{-1}$ recorded the maximum bacterial and fungal population in soil at different stages of banana growth except 3 month after planting. Actinomycetes population was also high under 75 per cent RDF along with either 40 per cent WG organic soil or 40 per cent WG organic grains. Soil organic carbon was also observed higher under this treatment when compared to chemical fertilizers. Hence, integrated nutrient management (75or 100\% recommended dose of fertilizer coupled with either FYM @ 10kg plant ${ }^{-1} / 40 \%$ Wellgro soil or grain) practices has been found to be an ideal option to improve biological properties and soil organic carbon in banana under soil climatic conditions of Western zone of Tamil Nadu.

\section{Introduction}

Microorganisms play a definitive and very crucial role in soil fertility. Although soil organisms comprise $<1 \%$ of the total mass of a soil, they have a vital role in supporting all plants and thus animals. Every gram of a typical healthy soil is home to several thousand different species of bacteria.
In addition to bacteria, soil is home to microscopic fungi, algae, cyanobacteria, Actinomycetes, protozoa and nematodes, and macroscopic earthworms, insects and the occasional wombat. Microorganisms play an important role in the decomposition of organic matter and also help in the 
decomposition of toxic waste and other pollutants. The diversity and abundance of life is in the soil more copious than in any other ecosystem. Microorganisms play a critical role in soil quality and support development of plants. They stimulate plant growth by facilitating the assimilation of phosphorus and iron, nitrogen fixation, releasing phytohormones, inhibiting root pathogens and synthesizing antibiotics (Glick, 1995).

Application of inorganic fertilizers though increases the yield substantially, could not sustain the fertility status of the soil (Bharadwaj and Omanwar, 1994) and have caused several undesirable consequences in the fragile soil eco-system, leading to gradual decline in productivity (Prabhuram, 1992; Vidhya, 2004). Considering the present situation of soil quality and environmental security, it is necessary to go for an integrated nutrient management, involving various sources of organic manures, organic cakes and bio-fertilizers besides using chemical fertilizers in banana. In today's cultivation many commercial organic manures are being used because of their application in lesser volume and also enriched with nutrients. One such commercial organic manure used in the study is Wellgro. Wellgroorganic manures are a product of Indian Tobacco Company (ITC) and are developed for soil application and foliar spray. These products are made from non-timber forest produce and rich source of nutrients and organic carbon. Across the country, its efficacy was examined in different agro climatic conditions on various crops.

The information on effect of integrated nutrient management practices on banana with commercial formulations of organic products (Wellgro) is new under the soil and climatic conditions of Western zone of Tamil Nadu. Keeping these aspects in view, the present research work was undertaken to study the effect of integrated nutrient management practices on growth and yield of banana under irrigated conditions.

\section{Materials and Methods}

The experiments were conducted during 2010-11 and 2011-12at Northern Block farm, Agricultural Research Station (Tamil Nadu Agricultural University), Bhavanisagar, Erode district of Tamil Nadu. The farm is geographically located at $11^{\circ} 29^{\prime} \mathrm{N}$ latitude and $77^{\circ} 08^{\prime} \mathrm{E}$ longitude at an altitude of $256 \mathrm{~m}$ MSL. The experiments were conducted under irrigated conditions. Throughout the experiment, the mean annual rainfall was $538.8 \mathrm{~mm}$ in 38 rainy days and 742.8 in 43 rainy days during first and second year, respectively. The mean maximum and minimum temperatures recorded were $33.8^{\circ} \mathrm{C}$ and $21.9^{\circ} \mathrm{C}$ in $2010-11$ and $34^{\circ} \mathrm{C}$ and $21.1^{\circ} \mathrm{C}$ in 2011-12. Similarly, the mean maximum and minimum relative humidity was 87.8 and $50.2 \%$ during $2010-11$ and 86.2 and $56.3 \%$ during 2011-12. Mean bright sunshine hours per day was 4.67 with a mean solar radiation of $453 \mathrm{cal} \mathrm{cm}^{2}$ day $^{-1}$.

The soil type was sandy loam in texture. The soil were neutral ( $\mathrm{pH} 7.06$ and 7.18) with low soluble salts (EC 0.263 and $0.254 \mathrm{dSm}^{-1}$ ), medium and low in organic carbon content $(0.51$ and $0.46 \%)$, low in available nitrogen (208 and $232 \mathrm{~kg} / \mathrm{ha}$ ), medium in available phosphorus (14.7 and $15.3 \mathrm{~kg} / \mathrm{ha}$ ) and high in available potassium (611 and $649 \mathrm{~kg} / \mathrm{ha}$ ) for 2010-11 and 2011-12, respectively. Similarly, soil bulk density was 1.35 and $1.28 \mathrm{~g} / \mathrm{cc}$, particle density was 2.27 and $2.31 \mathrm{~g} / \mathrm{cc}$ and porosity was 40.3 and $44.6 \%$ during 2010-11 and 2011-12, respectively.

Field experiments were laid out in Randomized Complete Block Design (RCBD) and treatments were replicated thriceas 
suggested by Gomez and Gomez (2010). Plot size was $14.4 \times 5.4 \mathrm{~m}^{2}(77.76 \mathrm{~m} 2)$ and plant spacing adopted was $1.8 \times 1.8 \mathrm{~m} 2$. Wellgro organic manures [Wellgro soil, Wellgro grains and Wellgro crops (liquid organic manure)] were used as organic source of nutrients. The banana cv. Grand Naine (AAA) was used as test crop in both the years of study.

The treatmentcomprises $\quad \mathrm{T}_{1^{-}} \quad 100 \%$ recommended dose of fertilizer (control), $\mathrm{T}_{2^{-}}$ $100 \% \mathrm{RDF}+$ Wellgro soil @ 20\% w/w of chemical fertilizers, $\mathrm{T}_{3}-100 \% \mathrm{RDF}+$ Wellgro soil @ 40\% w/w of chemical fertilizers, $\mathrm{T}_{4-}$ 75\% RDF + Wellgro soil @ 20\% w/w of chemical fertilizers, $\mathrm{T}_{5^{-}} 75 \% \mathrm{RDF}+$ Wellgro soil @ 40\% w/w ofchemical fertilizers, $\mathrm{T}_{6^{-}}$ $100 \%$ RDF + liquid organic manure spray (LOM) on bunches, $\mathrm{T}_{7-}-75 \% \mathrm{RDF}+$ liquid organic manure spray (LOM) on bunches, $\mathrm{T}_{8^{-}}$ $100 \% \mathrm{RDF}+$ Wellgro grains @ 20\% w/w of chemical fertilizers, $\mathrm{T}_{9}-100 \% \mathrm{RDF}+$ Wellgro grains@ @ $0 \% \mathrm{w} / \mathrm{w}$ of chemical fertilizers, $\mathrm{T}_{10^{-}} 75 \% \mathrm{RDF}+$ Wellgro grains @ 20\% w/w of chemical fertilizers, $\mathrm{T}_{11^{-}} 75 \% \mathrm{RDF}+$ Wellgro grains@ @ $0 \%$ w/w of chemical fertilizers, $\mathrm{T}_{12^{-}}$100\% RDF + FYM @ $10 \mathrm{~kg} / \mathrm{plant}$ and $\mathrm{T}_{13}-75 \% \mathrm{RDF}+\mathrm{FYM} @$ $10 \mathrm{~kg} /$ plant.

Method of application: 165: $495 \mathrm{~g}$ and 123.7: $371.3 \mathrm{~g} \mathrm{NK}$ plant $^{-1}$ were applied in four equal split doses at $2^{\text {nd }}, 4^{\text {th }}, 6^{\text {th }}$ and $8^{\text {th }}$ month after planting and total phosphorus (52.5 and 39.4 g P plant ${ }^{-1}$ ) and FYM @ $10 \mathrm{~kg}$ plant $^{-1}$ were applied in a single dose at $2^{\text {nd }}$ month after planting. Fertilizers and organic manures (quantity as per the treatment) were applied in the basins which were formed around the pseudostem at distance of $30 \mathrm{~cm}$ and closed after the application. Liquid organic manure @ 2\% was sprayed twice (i.e., at 15 and 30 days after last hand opening) uniformly on the foliage and developing bunches. The other recommended cultural practices were followed uniformly for raising the crop as per the Crop Production Techniques of Horticultural crops (2004).

\section{Soil biological properties}

The effect of organic manures on soil microorganisms was studied in the experiment field. Soil samples from each plot were taken at initial stage, 3and 5MAP, at shooting and at harvest stages of banana. The population of bacteria, fungi and actinomycetes population were specified in nutrient agar, Martin's rose Bengal agar and knight's media, respectively. The standard serial dilution plating techniques of Waksman and Fred (1922) was employed for the estimation of microbial population. The observation on number of colonies of bacteria, fungi and actinomycetes were taken at 1,3 and 7 days after inoculation respectively and expressed as colony forming units per gram of dry weight of soil.

The data were statistically analyzed by the analysis of variance method as suggested Gomez and Gomez (2010). Wherever the treatment differences were found significant, critical differences were worked out at 5 per cent probability level and the values are furnished. Non-significant treatment differences were denoted as NS.

\section{Results and Discussion}

\section{Bacterial population}

The data pertaining to bacterial population $\left(\mathrm{CFU} \mathrm{g}{ }^{-1}\right.$ ) recorded at 3 and $5 \mathrm{MAP}$, at shooting and at harvest stages are presented in Table 1. In general, bacterial count increased with advancement of ageing of banana crop and the maximum count was recorded at shooting stage and later, a slight decline at harvest stage. Bacterial load in soil at different stages are significantly influenced 
due to INM treatments in both the years except during 3 MAP in 2010-11. During 2010-11, at 5 MAP, all the INM treated plots recorded higher bacterial count except $\mathrm{T}_{8}, \mathrm{~T}_{6}$, $\mathrm{T}_{7}$ and $\mathrm{T}_{1}$. However, the highest bacterial count $\left(24.78 \times 10^{5} \mathrm{CFU} \mathrm{g}^{-1}\right)$ was observed with application of 75 per cent RDF + FYM @ 10kg plant ${ }^{-1}\left(\mathrm{~T}_{13}\right)$. At shooting and harvest stages also, $\mathrm{T}_{13}$ performed better on bacterial count than others. It recorded the maximum population of 37.95 and $38.62 \times 10^{5} \mathrm{CFU} \mathrm{g}^{-1}$ at shooting and harvest stages, respectively but was on par with $\mathrm{T}_{11}, \mathrm{~T}_{12}, \mathrm{~T}_{5}, \mathrm{~T}_{4}, \mathrm{~T}_{9}$ and $\mathrm{T}_{2}$ at shooting stage and with $\mathrm{T}_{12}$ and $\mathrm{T}_{3}$ at harvest stage. The least values of bacterial population were recorded in control plot $\left(\mathrm{T}_{1}\right)$ at $5 \mathrm{MAP}$ and $\mathrm{T}_{7}$ at shooting and at harvest stages of banana growth.

During 2011-12 year, at 3 MAP, the bacterial count was significantly higher $\left(15.30 \times 10^{5}\right.$ CFU g $\left.{ }^{-1}\right)$ with $\mathrm{T}_{5}(75 \% \mathrm{RDF}+40 \% W G$ organic soil) than control, but it was at par with $\mathrm{T}_{11}, \mathrm{~T}_{4}, \mathrm{~T}_{9}, \mathrm{~T}_{13}, \mathrm{~T}_{3}$ and $\mathrm{T}_{2}$. Application of 75 per cent RDF along with FYM @ 10kg plant $^{-1}\left(\mathrm{~T}_{13}\right)$ recorded the highest bacterial load (29.31 and $39.58 \times 10^{5} \mathrm{CFU} \mathrm{g}^{-1}$ ) at 5 MAP and at shooting stages, respectively. However, it was comparable with $\mathrm{T}_{11}$ and $\mathrm{T}_{3}$ at 5 MAP and with $\mathrm{T}_{11}, \mathrm{~T}_{5}$ and $\mathrm{T}_{10}$ at shooting stage. At harvest stage, application of 100 per cent RDF +40 per cent WG organic soil $\left(\mathrm{T}_{3}\right)$ recorded the maximum population $(36.86 \mathrm{x}$ $10^{5} \mathrm{CFU} \mathrm{g}^{-1}$ ) while, the lowest population was recorded in $\mathrm{T}_{7}$ at $3 \mathrm{MAP}$ and at harvest stages, $\mathrm{T}_{1}$ at $5 \mathrm{MAP}$ and $\mathrm{T}_{6}$ at shooting stage.

\section{Fungi population}

Data on results of fungal population due to nutrient management practices are furnished in Table 2. Barring 3 MAP, fungal load in soil at different stages was significantly influenced due to combined application of organic and inorganic fertilizers.
During 2010-11, at 5 MAP, significantly higher fungal population $\left(18.05 \times 10^{3} \mathrm{CFU} \mathrm{g}^{-}\right.$ $\left.{ }^{1}\right)$ was recorded with application of 100 per cent RDF + FYM @ 10kg plant ${ }^{-1}\left(\mathrm{~T}_{12}\right)$ but it was statistically on par with $\mathrm{T}_{13}$. At shooting stage, application of 75 per cent RDF + FYM@ $10 \mathrm{~kg}$ plant $^{-1} \quad\left(\mathrm{~T}_{13}\right)$ recorded significantly higher fungal population (21.93 $\mathrm{x} 10^{3} \mathrm{CFU} \mathrm{g}^{-1}$ ) but it was on par with $\mathrm{T}_{12}$ and $\mathrm{T}_{9}$. At harvest stage also, $\mathrm{T}_{13}$ recorded higher population $\left(22.90 \times 10^{3} \mathrm{CFU} \quad \mathrm{g}^{-1}\right)$ but registered on par results with $\mathrm{T}_{12}$. The lowest fungal population was recorded with $\mathrm{T}_{7}$ at 5 MAP and $\mathrm{T}_{6}$ at shooting and at harvest stages. During the second year, combined application of 100 per cent $\mathrm{RDF}+40$ per cent $W G$ organic grains $\left(\mathrm{T}_{9}\right)$ recorded the highest fungal population $\left(12.35 \times 10^{3} \mathrm{CFU} \mathrm{g}^{-1}\right)$ at 5 MAP and with $\mathrm{T}_{3}\left(18.48 \times 10^{3} \mathrm{CFU} \mathrm{g}^{-1}\right)$ at shooting stage. However, they were comparable with $\mathrm{T}_{3}, \mathrm{~T}_{12}$ and $\mathrm{T}_{13}$ at $5 \mathrm{MAP}$ and $\mathrm{T}_{3}, \mathrm{~T}_{9}, \mathrm{~T}_{4}$ and $\mathrm{T}_{10}$ at shooting stage. At harvest stage, application of 100 per cent RDF along with 40 per cent $W G$ organic grains $\left(\mathrm{T}_{9}\right)$ recorded the maximum fungal population (18.56 x 10 $0^{3} \mathrm{CFU} \mathrm{g}^{-1}$ ) However, the lowest population was observed in control $\left(7.18 \times 10^{3} \mathrm{CFU} \mathrm{g}^{-1}\right)$ at all the stages during 2011-12.

\section{Actinomycetes population}

The data on the effect of INM treatments on actinomycetes population are presented in Table 3. Actinomycetes load in soil at different stages is significantly influenced due to application of organic and inorganic sources of nutrients except at early stage (3 MAP) of banana during both the years.At 5 MAP, application of 75 per cent RDF +40 per cent $W G$ organic soil $\left(\mathrm{T}_{5}\right)$ registered higher actinomycetes (15.34 and $16.52 \times 10^{2}$ CFU g ${ }^{-1}$ ) during 2010-11 and 2011-12 years, respectively. It was on par with $\mathrm{T}_{11}, \mathrm{~T}_{12}, \mathrm{~T}_{4}$, $\mathrm{T}_{10}$ and $\mathrm{T}_{13}$ during 2010-11 and $\mathrm{T}_{11}, \mathrm{~T}_{4}, \mathrm{~T}_{13}$ and $\mathrm{T}_{12}$ during 2011-12. 
Table.1 Effect of integrated nutrient management on soil bacteria $\left(\mathrm{CFU} \times 10^{5} \mathrm{~g}^{-1}\right)$ at different stages of growth

\begin{tabular}{|c|c|c|c|c|c|c|c|c|}
\hline \multirow{2}{*}{ Treatments } & \multicolumn{4}{|c|}{ 2010-11 } & \multicolumn{4}{|c|}{ 2011-12 } \\
\hline & 3 MAP & 5 MAP & Shooting & At harvest & 3 MAP & 5 MAP & Shooting & At harvest \\
\hline $\mathrm{T}_{1}-100 \% \mathrm{RDF}$ (Control) & 15.83 & 18.22 & 26.58 & 25.32 & 10.32 & 15.52 & 22.85 & 20.35 \\
\hline $\mathrm{T}_{2}-100 \% \mathrm{RDF}+20 \% \mathrm{WS}$ & 18.36 & 22.63 & 33.46 & 31.89 & 13.25 & 22.35 & 27.35 & 28.32 \\
\hline $\mathrm{T}_{3}-100 \% \mathrm{RDF}+40 \% \mathrm{WS}$ & 17.94 & 21.65 & 32.83 & 36.94 & 13.85 & 27.12 & 34.24 & 36.86 \\
\hline $\mathrm{T}_{4}-75 \% \mathrm{RDF}+20 \% \mathrm{WS}$ & 18.30 & 21.97 & 33.58 & 33.02 & 14.37 & 23.12 & 31.53 & 35.64 \\
\hline $\mathrm{T}_{5}-75 \% \mathrm{RDF}+40 \% \mathrm{WS}$ & 18.32 & 23.27 & 35.17 & 33.17 & 15.30 & 25.30 & 39.01 & 32.54 \\
\hline $\mathrm{T}_{6}-100 \% \mathrm{RDF}+\mathrm{WC}$ spray & 15.30 & 18.96 & 26.94 & 25.65 & 11.02 & 16.32 & 21.25 & 20.95 \\
\hline $\mathrm{T}_{7}-75 \% \mathrm{RDF}+\mathrm{WC}$ spray & 15.46 & 18.24 & 25.19 & 23.94 & 10.24 & 17.25 & 22.67 & 18.12 \\
\hline $\mathrm{T}_{8}-100 \% \mathrm{RDF}+20 \% \mathrm{WG}$ & 17.45 & 21.20 & 31.20 & 30.21 & 11.85 & 19.47 & 30.57 & 28.62 \\
\hline $\mathrm{T}_{9}-100 \% \mathrm{RDF}+40 \% \mathrm{WG}$ & 17.84 & 23.06 & 34.95 & 33.62 & 14.25 & 24.20 & 33.60 & 31.29 \\
\hline $\mathrm{T}_{10}-75 \% \mathrm{RDF}+20 \% \mathrm{WG}$ & 18.20 & 22.57 & 32.57 & 34.11 & 12.54 & 20.86 & 35.95 & 32.42 \\
\hline $\mathrm{T}_{11}-75 \% \mathrm{RDF}+40 \% \mathrm{WG}$ & 18.51 & 22.55 & 37.28 & 32.64 & 14.98 & 27.35 & 38.18 & 36.84 \\
\hline $\mathrm{T}_{12}-100 \% \mathrm{RDF}+\mathrm{FYM}$ & 19.32 & 23.38 & 35.60 & 37.01 & 13.20 & 25.14 & 34.20 & 34.35 \\
\hline $\mathrm{T}_{13}-75 \% \mathrm{RDF}+\mathrm{FYM}$ & 18.98 & 24.78 & 37.95 & 38.62 & 14.12 & 29.31 & 39.58 & 36.78 \\
\hline S.Ed & 1.96 & 1.61 & 2.22 & 1.87 & 1.01 & 1.88 & 2.13 & 2.22 \\
\hline $\mathrm{CD}(\mathrm{P}=0.05)$ & NS & 3.33 & 4.59 & 3.88 & 2.09 & 3.89 & 4.41 & 4.59 \\
\hline
\end{tabular}

$100 \%$ RDF- 165:52.5:495g plant ${ }^{-1}$, WS- organic soil, WG- organic grain, WC -liquid organic manure spray on bunches, FYM - 10kg plant ${ }^{-1}$

Table.2 Effect of integrated nutrient management on soil fungi CFU $\times 10^{3} \mathrm{~g}^{-1}$ ) at different stages of growth

\begin{tabular}{|c|c|c|c|c|c|c|c|c|}
\hline \multirow{2}{*}{ Treatments } & \multicolumn{4}{|c|}{$2010-11$} & \multicolumn{4}{|c|}{ 2011-12 } \\
\hline & 3 MAP & 5 MAP & Shooting & At harvest & 3 MAP & 5 MAP & Shooting & At harvest \\
\hline $\mathrm{T}_{1}-100 \%$ RDF (Control) & 4.74 & 5.18 & 6.18 & 5.91 & 4.12 & 5.52 & 7.91 & 7.18 \\
\hline $\mathrm{T}_{2}-100 \% \mathrm{RDF}+20 \% \mathrm{WS}$ & 4.84 & 8.62 & 12.94 & 12.25 & 4.57 & 8.64 & 11.32 & 12.68 \\
\hline $\mathrm{T}_{3}-100 \% \mathrm{RDF}+40 \% \mathrm{WS}$ & 5.10 & 14.43 & 16.37 & 14.71 & 4.91 & 11.68 & 17.52 & 16.29 \\
\hline $\mathrm{T}_{4}-75 \% \mathrm{RDF}+20 \% \mathrm{WS}$ & 5.04 & 10.28 & 15.42 & 14.22 & 5.16 & 9.56 & 16.28 & 14.23 \\
\hline $\mathrm{T}_{5}-75 \% \mathrm{RDF}+40 \% \mathrm{WS}$ & 5.13 & 8.89 & 14.85 & 13.14 & 4.95 & 9.14 & 13.58 & 12.81 \\
\hline $\mathrm{T}_{6}-100 \% \mathrm{RDF}+\mathrm{WC}$ spray & 4.72 & 5.39 & 6.05 & 5.85 & 4.18 & 5.71 & 8.12 & 7.85 \\
\hline $\mathrm{T}_{7}-75 \% \mathrm{RDF}+\mathrm{WC}$ spray & 4.67 & 5.00 & 7.26 & 6.88 & 4.21 & 5.98 & 8.18 & 7.56 \\
\hline $\mathrm{T}_{8}-100 \% \mathrm{RDF}+20 \% \mathrm{WG}$ & 5.04 & 9.48 & 12.90 & 12.97 & 4.37 & 8.45 & 12.66 & 13.85 \\
\hline $\mathrm{T}_{9}-100 \% \mathrm{RDF}+40 \% \mathrm{WG}$ & 5.02 & 15.58 & 18.30 & 16.41 & 4.97 & 12.35 & 17.93 & 18.56 \\
\hline $\mathrm{T}_{10}-75 \% \mathrm{RDF}+20 \% \mathrm{WG}$ & 4.97 & 14.69 & 16.90 & 16.81 & 4.84 & 10.11 & 15.72 & 16.82 \\
\hline $\mathrm{T}_{11}-75 \% \mathrm{RDF}+40 \% \mathrm{WG}$ & 4.98 & 10.11 & 12.36 & 12.74 & 4.52 & 9.69 & 14.08 & 16.56 \\
\hline $\mathrm{T}_{12}-100 \% \mathrm{RDF}+\mathrm{FYM}$ & 5.19 & 18.05 & 20.27 & 20.86 & 4.87 & 11.87 & 14.85 & 14.31 \\
\hline $\mathrm{T}_{13}-75 \% \mathrm{RDF}+\mathrm{FYM}$ & 5.14 & 17.29 & 21.93 & 22.90 & 5.13 & 12.14 & 18.48 & 16.45 \\
\hline S.Ed & 0.29 & 1.09 & 2.03 & 1.85 & 0.50 & 1.02 & 1.48 & 1.51 \\
\hline $\mathrm{CD}(\mathrm{P}=0.05)$ & NS & 2.26 & 4.19 & 3.82 & NS & 2.12 & 3.06 & 3.11 \\
\hline
\end{tabular}

$100 \%$ RDF- 165:52.5:495g plant ${ }^{-1}$, WS- organic soil, WG- organic grain, WC -liquid organic manure spray on bunches, FYM - 10kg plant ${ }^{-1}$ 
Int.J.Curr.Microbiol.App.Sci (2017) 6(11): 2342-2350

Table.3 Effect of integrated nutrient management on soil actinomycetes $\left(\mathrm{CFU} \times 10^{2} \mathrm{~g}^{-1}\right)$ at different stages of growth

\begin{tabular}{|c|c|c|c|c|c|c|c|c|}
\hline \multirow[b]{2}{*}{ Treatments } & \multicolumn{4}{|c|}{$2010-11$} & \multicolumn{4}{|c|}{ 2011-12 } \\
\hline & 3 MAP & 5 MAP & Shooting & At harvest & 3 МАP & 5 MAP & Shooting & $\begin{array}{c}\text { At } \\
\text { harvest }\end{array}$ \\
\hline $\mathrm{T}_{1}-100 \%$ RDF (Control) & 4.74 & 6.09 & 10.28 & 10.22 & 5.38 & 7.19 & 10.51 & 9.30 \\
\hline $\mathrm{T}_{2}-100 \% \mathrm{RDF}+20 \% \mathrm{WS}$ & 4.84 & 10.53 & 20.29 & 20.19 & 5.75 & 10.85 & 17.84 & 17.42 \\
\hline $\mathrm{T}_{3}-100 \% \mathrm{RDF}+40 \% \mathrm{WS}$ & 5.13 & 11.91 & 23.43 & 22.27 & 5.89 & 12.97 & 22.32 & 21.85 \\
\hline $\mathrm{T}_{4}-75 \% \mathrm{RDF}+20 \% \mathrm{WS}$ & 5.04 & 13.84 & 20.90 & 21.21 & 6.03 & 15.62 & 20.43 & 19.36 \\
\hline $\mathrm{T}_{5}-75 \% \mathrm{RDF}+40 \% \mathrm{WS}$ & 5.10 & 15.34 & 26.50 & 20.86 & 6.09 & 16.52 & 24.85 & 26.11 \\
\hline $\mathrm{T}_{6}-100 \% \mathrm{RDF}+\mathrm{WC}$ spray & 4.72 & 6.18 & 10.62 & 10.50 & 5.41 & 7.87 & 10.92 & 9.58 \\
\hline $\mathrm{T}_{7}-75 \% \mathrm{RDF}+\mathrm{WC}$ spray & 4.67 & 5.84 & 9.86 & 9.52 & 5.40 & 8.02 & 10.64 & 9.23 \\
\hline $\mathrm{T}_{8}-100 \% \mathrm{RDF}+20 \% \mathrm{WG}$ & 5.04 & 10.49 & 19.31 & 20.14 & 5.34 & 12.53 & 16.89 & 18.47 \\
\hline $\mathrm{T}_{9}-100 \% \mathrm{RDF}+40 \% \mathrm{WG}$ & 4.98 & 10.98 & 21.41 & 22.35 & 5.72 & 11.24 & 19.68 & 20.32 \\
\hline $\mathrm{T}_{10}-75 \% \mathrm{RDF}+20 \% \mathrm{WG}$ & 4.97 & 13.24 & 22.49 & 21.31 & 5.84 & 13.68 & 22.63 & 22.88 \\
\hline $\mathrm{T}_{11}-75 \% \mathrm{RDF}+40 \% \mathrm{WG}$ & 5.02 & 15.09 & 24.85 & 22.49 & 6.04 & 15.81 & 25.38 & 25.74 \\
\hline $\mathrm{T}_{12}-100 \% \mathrm{RDF}+\mathrm{FYM}$ & 5.19 & 14.40 & 23.92 & 24.82 & 5.86 & 14.92 & 19.17 & 22.41 \\
\hline $\mathrm{T}_{13}-75 \% \mathrm{RDF}+\mathrm{FYM}$ & 5.14 & 13.11 & 24.69 & 25.14 & 5.92 & 15.27 & 23.75 & 24.10 \\
\hline S.Ed & 0.29 & 1.30 & 2.31 & 2.19 & 0.47 & 1.13 & 1.45 & 1.82 \\
\hline $\mathrm{CD}(\mathrm{P}=0.05)$ & NS & 2.67 & 4.77 & 4.52 & NS & 2.34 & 3.01 & 3.76 \\
\hline
\end{tabular}

100\% RDF- 165:52.5:495g plant ${ }^{-1}$, WS- organic soil, WG- organic grain, WC -liquid organic manure spray on bunches, FYM - 10kg plant ${ }^{-1}$ 
At shooting stage also, the highest number of actinomycetes $\left(26.50 \times 10^{2} \mathrm{CFU} \mathrm{g}^{-1}\right)$ was recorded in $\mathrm{T}_{5}(75 \% \mathrm{RDF}+40 \%$ WG organic soil) during 2010-11, which was comparable with $\mathrm{T}_{13}, \mathrm{~T}_{11}, \mathrm{~T}_{12}, \mathrm{~T}_{3}$ and $\mathrm{T}_{10}$. During 201112, application of 75 per cent $\mathrm{RDF}+40$ per cent $W G$ organic grains $\left(\mathrm{T}_{11}\right)$ registered higher actinomycetes $\left(25.38 \times 10^{2} \mathrm{CFU} \mathrm{g}^{-1}\right)$ compared to control and it was statistically at par with $\mathrm{T}_{5}, \mathrm{~T}_{13}$ and $\mathrm{T}_{10}$. At harvest stage, application of 75 per cent RDF + FYM @ $10 \mathrm{~kg}$ plant $^{-1} \quad\left(\mathrm{~T}_{13}\right)$ registered higher actinomycetes $\left(25.14 \times 10^{2} \mathrm{CFU} \mathrm{g}^{-1}\right)$ during 2010-11 and it was on par with $\mathrm{T}_{12}, \mathrm{~T}_{11}, \mathrm{~T}_{9}$, $\mathrm{T}_{3}, \mathrm{~T}_{10}, \mathrm{~T}_{4}$ and $\mathrm{T}_{5}$. During 2011-12, $\mathrm{T}_{5}(75 \%$ $\mathrm{RDF}+40 \% W G$ organic soil) recorded the highest population of actinomycetes $(26.11 \mathrm{x}$ $10^{2} \mathrm{CFU} \mathrm{g}^{-1}$ ) compared to control and it was statistically on par with $\mathrm{T}_{11}, \mathrm{~T}_{13}, \mathrm{~T}_{10}$ and $\mathrm{T}_{12}$. During both the years, the lowest population was recorded in $\mathrm{T}_{7}(75 \% \mathrm{RDF}+2 \%$ liquid organic manure spray on bunches) at all the stages of growth except 5 MAP and shooting stages in the second year

Soil microorganisms play a very important role in soil fertility not only because of their ability to carry out biochemical transformation, but also, due to their importance as a source and sink of mineral nutrients (Jenkinson and Ladd, 1981). Apart from this, soil microbes are the living part of soil organic matter, function as a transient nutrient sink and are responsible for releasing nutrients from organic matter for use by plants. The soil microbial community is involved in numerous ecosystem functions, such as nutrient cycling and organic matter decomposition and plays a crucial role in the terrestrial carbon cycle (Schimel, 1995). Cruz et al., (2008) also opined that the reactivation of microbial activity in rhizosphere can increase plant nutrient availability, since the soil microbial community mediates the process of organic matter turnover and nutrient cycling.
In the present study, the use of organic sources consists of bulky and concentrated organic manures which provided organic matter and mineral nutrients to soil. These organic manures also greatly increased the soil microbial population. Improved microbial load was observed under either 75 per cent RDF or 100 per cent RDF along with FYM $10 \mathrm{~kg}$ plant $^{-1}$ which was on par with 75 per cent RDF with 40 per cent $W G$ organic soil or $W G$ organic grains and 100 per cent RDF with 40 per cent $W G$ organic soil or $W G$ organic grains. Organic manure enhanced the microbial biomass than inorganic fertilizers because they increase the proportion of labile carbon and nitrogen directly by stimulating the activity of microorganism. Munoz (1994) described that the application of easily decomposable organic material in soil enriches both the fauna and flora in the soil environment and especially the bacterial population.

The organic addition coupled with NPK fertilization exerted a stimulating influence on the preponderance of bacteria in soil. This indicated that magnitude of easily degradable carbonaceous compound monitored the proliferation of bacterial population in soil and this is in line with the work of Dhakshinamoorthy et al., (2005). WG organic manure and FYM being totally natural, are compatible with soil microbes, improve rhizosphere microflora and hence ensures fertility of the soil. It might have increased the friability, aggregation of soil and increased level of humus thereby enhancing the soil microbial activity. The multiplication of microbes significantly improved the $\mathrm{N}$ supply of soil. Moreover, organic manure helps to retain moisture for long time. This factor would have led to increased microbial activity in soil. Application of organic manures increased the microbial population viz., fungi, bacteria and actinomycetes than recommended dose of fertilizers. This is in 
accordance with the findings of Easwaran (2002) in tea, Kajal et al., (2008) in bhendi and Goyal et al., (2009) in rice. Kang et al., (2005) revealed increase in bacterial number in response to chemical fertilizers which may be attributed to a better nutrient status of the soil. Likewise, fungal population showed positive correlation with organic carbon in all the treatments. In contrast, Scullion and Ramshaw (1987) reported that application of organic manure encouraged costing and burrowing to the surface, whereas, application of inorganic fertilizers discouraged these activities.

Application of organic manures and biofertilizers (Azospirillum brasilense and Phosphobacteria) either singly or in combination with fertilizers resulted in positive influence on microbial biomass carbon, $\mathrm{N}$ mineralization, soil respiration and enzyme activities (Dinesh and Pandey, 2010). This evidence supported the present findings with FYM and $W G$ organic manure. In addition, organic inputs improved the biological activity in the rhizosphere zone, thus increasing populations of arbuscular mycorrhizal fungi, favouring plant growth, promoting rhizobacteria, actinomycetes and beneficial free living nematodes and inducing better plant tolerance to biotic and abiotic stresses. This is in confirmation with earlier work of Cabrera (2010); Harish and Devasenapathy (2010); and Bibhuti and Dkhar (2011).

Beyond this, soil organic carbon serve as a food for soil fauna and flora and soil organic matter play an important role in the food web by controlling the number and types of soil inhabitants, which serve important functions such as nutrient cycling and availability, assisting root growth and plant nutrients uptake (Chan, 2010). The changes in soil organic carbon contents are directly associated with the changes in microbial biomass carbon and biological activity in the soil (Nakhro and Dkhar, 2010).

Biological load in soil was significantly influenced through INM treatments during both the years at all stages except early stage. Among the treatments, application of 75 per cent RDF+FYM @ 10kg plant ${ }^{-1}$ recorded the maximum bacterial andfungal population in soil at different stages of banana growth. Similarly Actinomycetes population was also high under 75 per cent RDF along with either 40 per cent $W G$ organic soil or 40 per cent $W G$ organic grains.

Hence, it could be concluded that addition of organic manures along with recommended dose of fertilizer to be an ideal option to sustain soil fertility in terms of biological properties, soil organic carbon and crop productivity besides being economically competitive and productive under soil and climatic conditions of Western zone of Tamil Nadu.

\section{References}

Bharadwaj V, Omanwar P.K., 1994. Long term effects of continuous rotational cropping and fertilization on crop yields and soil properties- II. Effects on EC, $\mathrm{pH}$, organic matter and available nutrients of soil. J. Indian Soc. Soil Sci., 42(3): 387-392.

Bibhuti B.D, Dkhar M.S., 2011. Rhizosphere microbial populations and physical chemical properties as affected by organic and inorganic farming practise. AmericanEurasian J. Agric. \& Environ, Sci., 10(2): 140-150.

Cabrera J.C., 2010. Banana production under integrated pest management and organic production criteria: In: Banana case studyguide no. 5. Science to field (Ed.), ICIA, Spain.

Chan Y., 2010. Increasing soil organic carbon of agricultural land. Prime facts (735). In: www.dpi.nsw.gov.au

Crop Production Techniques of Horticultural 
crops., 2004. Published by Directorate of Horticulture and Plantation crops, Chennai and Tamil Nadu Agrl. Univ., Coimbatore. pp 4-8.

Cruz R, Antonio T.N, Georgina C.B, Josef K.F.C, Antonio R., 2008. Poultry manure and banana waste are effective bio-fertilizer carriers for promoting plant growth and soil sustainability in banana crops. Soil Biol. \& Biochem., 40: 3092-3095.

Dhakshinamoorthy M., Singh M.V, Malarvizhi P, Selvi D, Bhaskaran A., 2005. In: Soil quality, crop productivity and sustainability as influenced by long term fertilizer application and continuous cropping of finger millet-maize-cowpea in Swell-shrink soil. Research Bulletin No. 3, AICRP long term fertilizer experiments to study changes in soil quality, crop productivity and sustainability, ICAR-AICRP LTFE center, Dept. Soil Science and Agricultural Chemistry, TNAU, Coimbatore. pp.1-124.

Dinesh K, PandeyV.,2010. Relationship of pseudostem cross-sectional area with bunch weight, fruit quality and nutrient status in banana cv. Rasthali (Pathkapoora- AAB). Indian J. Hort., 67(1): 26-29.

Easwaran S., 2002. Studies on the effect of integrated nutrient management on soil health, growth and productivity of tea (Camellia sp.). Ph.D., (Hort.) Thesis. Tamil Nadu Agrl. Univ., Coimbatore.

Gomez K.A, Gomez A.A, 2010. Statistical Procedures for Agricultural Research.

Goyal S, Singh D, Suneja S, KapoorK.K., 2009. Effect of rice straw compost on soil microbiological properties and yield of rice. Indian J. Agrl. Res., 43(4): 263-268.

Harish H, Devasenapathy M., 2010. Microbial population dynamics as influenced by the application of organic manures in rice field. Green Farming, 1(4): 356-359.

Jenkinson D.S, Ladd J.N., 1981. Microbial biomass in soil. Measurement and turnover.
In: Soil and biochemistry. Paul, E.A. and J.N. Ladd (Eds.), Marcel Dekker, New York, USA. pp. 415-471.

Kajal A, Patil A.S, Dipti S, Waghdhare A., 2008. Influence of integrated plant nutrient supply on physical and biological properties of soil and yield of okra (Abelmoschus esculentus L. monech). Asian J. Soil Sci., 3(1): 36-39.

Kang G.S, Beri V, Rupela O.P, Sidhu B.S., 2005. A new index to assess soil quality and sustainability of wheat based cropping systems. Biol. Fertility. Soils, 41: 389-398.

Munoz A.R., 1994. Organicfertilizersand their usein agriculture.In:Soil Fertility, diagnostic and control, Silva, M.F. (Ed.). Colombian Society ofsoil science. SantafaBogota.Colombia.

Nakhro N., Dkhar M.S., 2010. Impact of organic and inorganic fertilizers on microbial populations and biomass carbon in paddy field soil. J. Agron., 9(3): 102-110.

Prabhuram R., 1992. Effect of organic manures and urea on the growth and development of banana cv. Rasthali and changes in the soil ecosystem. M.Sc. (Hort.) Thesis, Tamil Nadu Agrl. Univ., Coimbatore.

Schimel D.S., 1995. Terrestrial ecosystem and carbon cycle. Global Change Biol., 1: 7791.

Scullion, J. and G.A. Ramshaw. 1987. Effects of various manurial treatments on earthworm activity in grassland. Biol. Agric. Hort., 4: 271-281.

Vidhya D., 2004. Studies on the effect of biofertilizer on banana cv. Robusta (AAA) at varying doses of inorganic fertilizers. M.Sc. (Hort.), Thesis, Tamil Nadu Agrl. Univ., Coimbatore.

Waksman S.A, Fred E.B., 1922. A Tentative Outline of the Plate Method for Determining the Number of MicroOrganisms in the Soil. Soil Sci., 14(1): 2728.

\section{How to cite this article:}

Kuttimani, R., E. Somasundaram and Velayudham, K. 2017. Effect of Integrated Nutrient Management on Soil Microorganisms under Irrigated Banana. Int.J.Curr.Microbiol.App.Sci. 6(11): 2342-2350. doi: https://doi.org/10.20546/ijcmas.2017.611.277 